\title{
MENYOAL FAKTA PUSARA KORBAN, MEMBANGUN BUDAYA DAMAI DI HALMAHERA
}

\author{
SEFNAT HonTONG*
}

\begin{abstract}
Among the interesting phenomena in Halmahera's postconflict era are the permanently built tombs of victims in the courtyards of houses of worship (churches and mosques). An important question which arises from this phenomenon is: why were the tombs of victims built in the courtyards of the houses of worship? What is the meaning of this reality for promoting reconciliation and peace in Halmahera? According to the writer, an analysis on the way the Halmaherans comprehend this practice is important. By understanding the way the Halmahera people view and live out the meaning of the tombs of the victims, we can understand and anticipate any further impact of this practice. Through this article, the writer offers a sociological and theological study so that a road to promote peace building in Halmahera can be paved.
\end{abstract}

Keywords: Tomb of victims, martyr, syuhada, conflict, violence, reconciliation, peace, Halmahera.

Abstrak: Salah satu fenomena menarik dalam masyarakat Halmahera di era pasca konflik adalah adanya pusara korban yang dibangun secara permanen di halaman rumah ibadah (gereja dan masjid). Pertanyaan penting yang perlu dikemukakan melihat fenomena ini adalah: mengapa pusara korban dibangun di halaman rumah ibadah? Apa arti realita itu bagi upaya rekonsiliasi dan pembangunan budaya damai di Halmahera? Menurut penulis, kajian dan analisis terhadap penghayatan dan pemahaman masyarakat Halmahera terhadap realita pusara korban menjadi hal yang penting untuk dilakukan. Dengan memahami penghayatan dan pemahaman masyarakat Halmahera terhadap realita pusara korban, maka dampak yang ditimbulkan olehnya dapat

* Sefnat Hontong, Fakultas Teologi, Universitas Halmahera, Jl. Trans Tebelo-Galela, Kecamatan Tobelo, Kabupaten Halmahera Utara, Maluku Utara 97762. E-mail: sefnathontong@yahoo.co.id. 
dipahami, dimengerti, dan diantisipasi. Melalui artikel ini penulis hendak menampilkan sebuah kajian sosiologis-teologis dalam rangka menemukan sebuah "jalan raya" bagi upaya membangun perdamaian yang sejati di era pasca konflik di Halmahera.

Kata-kata kunci: Pusara korban, martir, syuhada, konflik, kekerasan, rekonsiliasi, perdamaian, Halmahera.

\section{PENDAHULUAN}

Salah satu fenomena menarik dalam masyarakat Halmahera di era pasca konflik adalah adanya pusara ${ }^{1}$ korban yang dibangun secara permanen di halaman rumah ibadah, baik gereja maupun masjid. René Girard - seorang kritikus sastra asal Perancis - menegaskan bahwa tradisi membangun atau memelihara pusara korban seperti ini dapat berakibat fatal bagi kehidupan masyarakat. Menganalisis teks Injil Lukas 11:47-48, Girard menegaskan bahwa orang-orang Yahudi dalam teks tersebut jelas ingin membangun pusara para nabi dengan tujuan untuk menghormati dan menghargai mereka, tetapi pada saat yang sama mereka sekaligus telah menelanjangi dan membenarkan tindakan pembunuhan yang dilakukan oleh leluhur mereka. Dengan membangun pusara itu, mereka memperlihatkan diri bahwa mereka juga terlibat dalam lingkaran peristiwa pembunuhan itu. ${ }^{2}$

Jika fenomena pembangunan pusara korban merupakan fakta adanya "dukungan moral pembunuhan" di masa kini oleh para pembangun pusara korban terhadap fakta pembunuhan yang telah terjadi di masa lampau, maka tidak mustahil hal itu dapat mendorong timbulnya niat balas dendam yang berkepanjangan oleh orang-orang yang membangun pusara korban terhadap orang-orang yang dianggap (dicap) sebagai pembunuh para korban. Apabila niat dan sikap saling balas dendam seperti itu akan menjadi bagian yang tak terpisahkan dari

1 Pusara artinya kubur atau kuburan. W.J.S. Poerwadarminta, Kamus Umum Bahasa Indonesia. Edisi ketiga (Jakarta: Balai Pustaka, 2006), hlm. 926.

2 Sindhunata, Kambing Hitam: Teori René Girard (Jakarta: Gramedia, 2006), hlm. 239246. 
kehidupan masyarakat-sebagai akibat dari fakta pembangunan pusara korban-maka pertanyaan yang muncul adalah bagaimanakah "nasib" masyarakat Halmahera di masa kini dan masa depan? Kegelisahan inilah yang telah mendorong penulis untuk membuat kajian ini.

\section{PUSARA KORBAN DALAM TRADISI MASYARAKAT}

Dulu, sebelum agama Islam dan Kristen masuk ke Halmahera, di Galela orang sudah biasa memelihara jasad orang mati, yang disebut dengan salabe dan wonge. Salabe ialah tradisi memelihara jasad orang mati yang dilakukan oleh setiap keluarga, sedangkan wonge adalah tradisi memelihara jasad orang mati yang dilakukan oleh sebuah komunitas masyarakat. Salabe dibangun di setiap rumah dan diletakkan di loteng, sedangkan wonge dibangun di sebuah lokasi tertentu yang disepakati secara bersama-sama oleh masyarakat.

Umumnya tempat meletakkan jasad orang mati dalam tradisi itu adalah para-para yang disebut lang (Galela). Sedangkan jasad orang mati yang berhak diletakan di salabe dan wonge adalah jasad dari orangorang yang berjasa, baik dalam keluarga maupun dalam sebuah komunitas; misalnya, orang yang pertama kali datang di suatu desa, pemimpin perang, ketua adat, kepala desa, pemimpin agama, pahlawan-

pahlawan yang mati dalam perang, dan sejumlah orang yang dianggap mempunyai kesaktian. ${ }^{3}$

3 Dalam sebuah wawancara yang penulis lakukan dengan Zadrak Tongo-Tongo (tokoh adat Tobelo) pada pada 15 Oktober 2007, di wilayah-wilayah lain di Halmahera juga dikenal tradisi yang sama tetapi dengan nama dan sistem yang agak berbeda dengan wilayah Galela. Di wilayah Tobelo, misalnya, tidak dikenal nama khusus untuk penghayatan secara kekeluargaan seperti di Galela, melainkan hanya dikenal nama penghayatan secara komuniter, yaitu "Halu." Sementara dalam sebuah wawancara yang penulis lakukan dengan seorang tokoh masyarakat Sahu di wilayah Sahu, Halmahera Barat, pada 15 Oktober 2007, sistem ini tidak ada bagi kepentingan komunitas, tetapi hanya untuk kepentingan keluarga (berbeda dengan Tobelo), yang disebut dengan "Bale," yaitu peletakan jasad leluhur/orang mati dalam keluarga (seperti "Salabe" di Galela). Lihat juga J. Haire, Sifat dan Pergumulan Gereja Halmahera 1941-1979 (Jakarta: BPK Gunung Mulia, 1998) hlm. 253. 
Tampaknya tradisi itulah yang telah melatari masyarakat di Halmahera dalam membangun pusara korban secara permanen di halaman rumah ibadah. Pada sisi yang lain, penulis juga melihat bahwa ternyata tradisi salabe dan wonge tersebut juga secara tidak langsung telah memperkuat penggunaan kata "martir" dan "syuhada" yang dialamatkan kepada para korban. Hal ini disebabkan oleh dua alasan.

Pertama, tradisi salabe dan wonge adalah tradisi yang berhubungan dengan peri laku masyarakat dalam rangka menghargai orang-orang yang dianggap berjasa dalam suatu komunitas. Kedua, dalam tradisi salabe dan wonge juga terkandung konsep-konsep yang berkaitan erat dengan hal-hal religius, seperti: pengabdian dan pengorbanan yang sangat dihargai dalam suatu komunitas religius. Dalam hal ini masyarakat dan keluarga korban mau tidak mau didorong untuk belajar dari pengalaman masa silam "para leluhur" mereka tentang berbagai pengorbanan ketika "bersaksi" tentang sebuah kebenaran sampai titik darah yang terakhir. Malahan dapat dikatakan bahwa dengan adanya tradisi salabe dan wonge, maka makna "martir" dan "syuhada" yang dialamatkan kepada para korban justru semakin menjadi kuat dan beralasan religius.

Dalam hal ini, benarlah apa yang dikemukakan oleh Bernard AdeneyRissakota dalam teori "Tiga Jaringan Makna": bahwa realita masyarakat Indonesia pada dasarnya dibentuk oleh perpaduan tiga jaringan makna yang berbeda tetapi sulit dipisahkan dan dipertentangkan. Tiga jaringan makna itu adalah jaringan makna budaya nenek moyang, jaringan makna agama, dan jaringan makna modernitas. Jaringan makna yang satu tidak dapat menghilangkan jaringan makna yang lain, melainkan secara dinamis dan terus-menerus masing-masing jaringan akan memperoleh maknanya berdasarkan perpaduan dengan jaringan yang lain. Oleh karena itu, "tipologi tiga jaringan makna" ini harus dipahami sebagai suatu struktur hidup dan pola berpikir masyarakat dalam membangun hubungan-hubungan sosialnya. ${ }^{4}$

4 Bernard Adeney-Risakotta, "Modernitas, Agama dan Budaya Nenek Moyang: Suatu 
Berdasarkan pemikiran seperti itu, dapat dikatakan bahwa realita pusara korban bisa eksis karena dilatari oleh sejumlah tradisi yang hidup dalam masyarakat, baik yang berasal dari budaya nenek moyang, agama, maupun modernitas. Dari sudut budaya nenek moyang realita pusara korban merupakan representasi dari tradisi salabe dan wonge, yang memperlihatkan kecenderungan memelihara jasad orang-orang yang dianggap berjasa dalam masyarakat, serta terkait juga dengan kepercayaan terhadap "roh-roh" orang mati. Tradisi tersebut kemudian berpadu makna dengan tradisi agama Kristen dan Islam yang berkaitan dengan konsep "martir" dan "syuhada" sehingga melahirkan konsep tentang para korban sebagai orang yang telah berjuang demi mempertahankan kebenaran agamanya, serta bertebarannya simbol-simbol agama di pusara korban.

Harus diakui bahwa setelah terjadi perpaduan makna dengan jaringan makna agama dan modernitas, ada sejumlah unsur dalam tradisi salabe dan wonge yang mengalami perubahan; misalnya tempat meletakkan jasad orang-orang yang dianggap berjasa tidak lagi dibuat dalam bentuk para-para (lang), ${ }^{5}$ tetapi dibuat dalam bentuk sebuah bangunan yang permanen, yaitu bangunan pusara.

Sebaliknya, oleh karena adanya pengaruh jaringan makna agama dan modernitas, tradisi salabe tidak dapat dibangun lagi secara fisik, karena dianggap dapat bertentangan dengan nilai-nilai agama; maka perwujudannya terungkap dalam satu wadah, yaitu dalam bentuk wonge secara baru yakni pusara korban yang dilengkapi dengan sejumlah

Model Masyarakat Indonesia," (sebuah makalah yang menyederhanakan salah satu bab dari buku yang belum terbit), hlm. 3-9. Lihat juga Bernard Adeney-Risakotta, "Teori Kekuasaan Dari Bawah," (sebuah makalah yang disampaikan pada seminar Internasional ke-3 “Dinamika Politik Lokal di Indonesia: Pluralitas dalam Perspektif Lokal," di Yayasan Percik, Salatiga, pada 9-12 Juli 2002, dan diterbitkan dalam Renai 3/1 (Juli 2002): 123-141.

5 Haryo S. Martodirjo menjelaskan bahwa para-para (lang) yang berada di bawah atap rumah adalah satu bagian dari sistem rumah di Halmahera yang berfungsi sebagai tempat untuk meletakkan makanan dan minuman bagi roh leluhur. Haryo S. Martodirjo, "Organisasi Sosial Orang Tugutil di Halmahera," dalam L.E. Visser, Halmahera and Beyond (Leiden: KITLV Press, 1994), p. 120. 
simbol agama. Begitu pula oleh karena adanya pengaruh jaringan makna agama, maka segenap ritual yang berlaku dalam tradisi salabe dan wonge tidak lagi dilakukan seperti aslinya, tetapi dilakukan dalam bentuk ziarah dan doa pergumulan serta beberapa aktivitas oleh pribadi dan keluarga korban pada hari-hari tertentu, serta adanya penempatan sejumlah simbol agama di pusara korban.

\section{DAMPAK PUSARA KORBAN DAN NILAI KEKERASANNYA}

Setelah melihat latar belakang pembangunan pusara korban dalam tradisi masyarakat, pertanyaan yang muncul berikutnya adalah apa dampak dari tradisi itu bagi upaya membangun perdamaian di Halmahera? Berikut ini adalah tiga hal penting yang menurut penulis harus sungguh-sungguh diperhatikan.

\section{Martir Sebagai Pejuang Agama: Wujud Paham Proselitisme Mutlak}

Pada umumnya masyarakat Halmahera menyebut para korban konflik sebagai martir (syuhada). Menurut hemat penulis pandangan ini dapat berdampak pada dua hal.

Pertama, dampak bagi mental dan tindakan pembenaran diri sendiri. Para pembangun pusara korban akan cenderung menganggap diri sebagai orang-orang "benar," sedangkan orang lain (bukan pembangun) adalah orang-orang yang telah "bersalah," dan harus bertanggungjawab atas kematian para korban yang dianggap sebagai martir/syuhada. Para pembangun pusara korban akan merasa diri bebas dari peristiwa kekerasan yang telah terjadi, sedangkan orang lain yang berada di luar dirinya harus dituntut karena telah menyebabkan kematian para korban.

Kedua, dampak bagi proses pengkultusan atau pengsakralisasian pengorbanan korban. Memang pengorbanan adalah sesuatu yang penting dalam kehidupan dan eksistensi manusia beragama, asalkan pengorbanan itu didasarkan pada cinta kasih yang tulus, tanpa pamrih dan tanpa kekerasan. Di satu pihak, akan terburu-buru jika dikatakan bahwa para korban dalam konflik Halmahera tidak mewujudkan 
pengorbanannya dengan nilai-nilai tersebut. Tetapi, di lain pihak, juga tidak mustahil untuk beranggapan bahwa anggota keluarga korban pada generasi yang berikut akan beranggapan bahwa para korban yang telah dibunuh itu adalah orang-orang yang benar, tetapi telah dibunuh secara sewenang-wenang oleh orang lain. Akibatnya adalah anggota keluarga korban pada masa depan dapat didorong membunuh orang lain yang dianggap sebagai pembunuh anggota keluarganya dengan alasan-alasan yang mengandung "kebenaran." Selanjutnya, oleh karena alasan-alasan "kebenaran" itulah maka kekerasan atas nama agama dan atas nama "kebenaran" bisa menjadi struktur dan sistem sosial dalam masyarakat. Konsep-konsep, seperti, pembenaran diri, pengkultusan dan sakralisasi terhadap pengorbanan para korban akan menjadi suatu ritual khusus dan simbol bagi masyarakat untuk mendukung kekerasan atas nama agama. ${ }^{6}$

Menurut Karin Andriolo praktik pembenaran diri, pengkultusan, dan sakralisasi pengorbanan seperti itu dapat pula mengantar orang untuk terlibat dalam aksi-aksi kekerasan atas nama agama. Hal itu dilakukan dengan cara membunuh pihak lain yang dianggap sebagai "musuh" sekaligus membunuh diri sendiri, seperti kasus bom bunuh diri. ${ }^{7}$

Dengan begitu, maka praktik pembenaran diri sendiri, pengkultusan terhadap para korban, dan sakralisasi terhadap sebuah pengorbanan diri-sebagai akibat dari penggunaan kata martir dan syuhada sebagai orang-orang yang berjuang mempertahankan kebenaran agama-adalah hal yang berbahaya dan perlu diwaspadai dalam kehidupan beragama.

Dalam alur pemikiran yang sama, Laurence R. Iannaccone dan Eli Berman menganggap bahwa konsep pembenaran diri, pengkultusan, dan sakralisasi pengorbanan dalam konteks kekerasan atas nama agama,

6 Francois Houtart, "Kultus, Kekerasan Atas Nama Agama: Sebuah Panorama," dalam Wim Beuken, et al., eds., Agama Sebagai Sumber Kekerasan? Terjemahan Imam Baehaqie (Yogyakarta: Pustaka Pelajar, 2003), hlm. ix-x.

7 Karin Adriolo, "Membunuh Melalui Bunuh Diri -Tiga Episode dari Sejarah Islam," dalam Ahmad Norma Permata, ed., Agama dan Terorisme (Surakarta: Muhammadiyah University Press, 2006), hlm. 35-55. 
adalah bagian dari konsep yang dibangun dalam eksistensi "agama ekstrim," dimana kekerasan dijadikan sebagai alat untuk melawan "musuh" yang dianggap "kafir" dan wujud pelayanan terhadap "tuhan." 8 Sementara itu, Emanuel Gerrit Singgih menyebut hal ini sebagai paham proselitisme mutlak, yaitu paham yang mengandung semangat untuk menjadikan orang lain supaya memeluk agama yang dianutnya, karena agama sendiri adalah yang paling "benar" sedangkan agama orang lain adalah yang paling "sesat."

\section{Simbolisasi Pusara Korban Menunjang Proses Mimesis Kekerasan}

Selain gelar martir (syuhada), realita pusara korban juga dibentuk oleh simbol salib, terutama yang dibangun oleh masyarakat yang beragama Kristen. Ada yang diletakkan dalam bentuk gambar pada batu nisan, ada juga yang dibangun dalam bentuk bangunan seperti monumen atau tugu. Di samping itu, ada juga simbol lain dalam bentuk kalimat yang dikutip dari pengalaman dan sejarah kehidupan beriman, dari Kitab Suci, maupun dari bahasa setempat: "Taman Dodara;"10 "Bagiku hidup adalah Kristus dan mati adalah keuntungan (Filipi 1:21)," "Berharga di mata Tuhan kematian semua orang yang dikasihi-Nya (Mzm 116:15);" "Darah para martir itu adalah benih bagi Gereja;" dan "Martir jemaat."

Tampaknya penggunaan simbol salib dan sejumlah pernyataan itu dapat membantu keluarga korban menjalani realitas konflik dengan kekuatan psikhe yang teguh dan kokoh. Kekuatan psikologis seperti ini, pada satu pihak, adalah hal yang baik bagi masyarakat pasca konflik, karena dapat menjadi dasar semangat bagi mereka untuk melangkah ke depan. Tetapi, di pihak lain, jika kekuatan psikologis itu semata-mata

8 Laurence R. Iannaccone and Eli Berman, "Religious Extremism: The good, the bad, and the deadly," Public Choice 128/1 (July 2006): 109-129.

9 Emanuel Gerrit Singgih, Mengantisipasi Masa Depan: Berteologi Dalam Konteks di Awal Milenium III (Jakarta: BPK Gunung Mulia, 2004), hlm. 59. Istilah proselitisme mutlak tersebut selanjutnya akan penulis manfaatkan untuk menggambarkan pemahaman keberagamaan masyarakat di Halmahera.

10 Bahasa Galela, artinya taman kasih Tuhan. 
bergantung pada sejumlah kalimat-yang secara sosiologis bermakna ganda dan multi tafsir - maka kondisi tersebut mengandung "bahaya," sebab godaan mengidealkan cara kematian korban akan selalu terbuka untuk ditiru dan kematian mereka dianggap sebagai kematian yang "layak" dan "berkenan."

René Girard menyebut proses itu dengan istilah mimesis, dari kata mime yang berarti "tiru." Dalam proses mimesis orang-orang yang memaknai dan memanfaatkan sejumlah simbol yang ada dalam masyarakat didorong bertingkah laku atau berbuat sama dengan apa yang disimbolisasikan, karena hal itu dianggap sebagai sesuatu yang ideal untuk ditiru. ${ }^{11}$ Para korban dengan sejumlah simbol dan makna kalimat yang melekat dalam dirinya itu, akan menjadi being atau model yang ideal bagi para penganut agama ekstrim untuk ditiru. Dalam diri mereka akan terbangun sedemikian rupa konsep yang ideal tentang kematian yang dijalani oleh para korban sebagai kematian yang layak dan berkenan di hadirat "tuhan." Orientasi kehidupan orang akan cenderung diarahkan kepada bagaimana ia dapat mewujudkan kematian yang "suci" dan "berkenan" tersebut, sehingga orang itu tidak dapat mengontrol lagi sesuatu yang sedang ia hadapi. Contoh-contoh seperti kasus bom bunuh diri adalah wujud dari orang yang terobsesi dengan hal pengorbanan diri secara berlebihan.

\section{“Jangan Sia-siakan Perjuanganku" Sebagai Benih Balas Dendam}

Satu kalimat yang banyak mengundang kontroversi pemaknaan di kalangan masyarakat Halmahera adalah kalimat yang tertulis pada batu nisan pusara korban di halaman gedung gereja desa Duma: "Jangan Sia-siakan Perjuanganku."

Bagi masyarakat Duma, kalimat itu berarti: warga masyarakat diminta melanjutkan perjuangan namun bukan dalam arti perang atau kekerasan, melainkan membangun kehidupan agar lebih baik dan lebih

11 Sindhunata, Kambing Hitam: Teori René Girard, hlm. 85-94. Lihat juga René Girard, Ayub Korban Masyarakat. Terj. Daniel K. Listijabudi (Jakarta: BPK Gunung Mulia, 2003), hlm. 11-16, 61-115. 
berkualitas di masa depan. Namun dalam realita masyarakat secara umum kalimat tersebut mengandung arti yang berlawanan dengan pemaknaan yang diharapkan oleh masyarakat Duma. Menurut masyarakat umum, kalimat itu menurut tradisi menjadi pesan dari orang mati kepada orang-orang yang masih hidup untuk terus melanjutkan perjuangan dengan melakukan perang dan kekerasan.

Jika penafsiran seperti itu dihubungkan dengan paham proselitisme mutlak seperti yang telah dijelaskan di atas, maka yang akan menjadi horizon awali dalam melakukan tafsiran terhadap kalimat tersebut sudah pasti adalah perang, kekerasan, dan konflik atas nama agama.

\section{REKONSILIASI SEBAGAI KRITIK DIRI, ARAH BERTEOLOGI DI HALMAHERA}

Memperhatikan tiga nilai kekerasan di atas, pertanyaan yang muncul adalah apa yang dapat dilakukan oleh masyarakat Halmahera di era pasca konflik ini? Menurut penulis, langkah pertama yang dapat dilakukan adalah melakukan kritik diri atau disiplin penilain. Dalam teologi Kristen kritik diri atau disiplin penilaian adalah sikap kritis terhadap situasi di sekitar yang dilakukan atas dasar Injil Yesus Kristus, yaitu dengan cara mengkonfirmasikannya atau mengkonfrontasikannya. Menurut Paulus S. Widjaja, dalam kerangka pemberdayaan masyarakat sebagai pelaku perdamaian, kritik diri adalah bagian yang paling penting, yaitu membangun sikap kritis terhadap nilai-nilai kekerasan yang ada dalam sistem sosial masyarakat. ${ }^{12}$

Pertanyaannya adalah manakah sistem sosial masyarakat di Halmahera yang dalam dirinya mengandung nilai-nilai kekerasan untuk dikritisi? Menurut penulis, sistem sosial itu adalah paham proselitisme mutlak yang telah berurat-akar dalam pemahaman keberagamaan masyakat. Jika paham proselitisme mutlak tetap terbangun dalam wawasan dan "nalar" masyarakat, maka kekerasan atas nama agama dan "tuhan"

12 Paulus S. Widjaja, "Menuju Masyarakat Damai Sejahtera." Artikel disampaikan dalam Sarasehan Lustrum IV GKJ Condongcatur, Yogyakarta, pada 16 Juni 2004, hlm. 5-6 
tidak akan terhindarkan dari eksistensi masyarakat. Selanjutnya, jika "nalar" kekerasan atas nama agama dan "tuhan" adalah sesuatu yang tidak terhindarkan, berarti kekerasan tersebut dipandang sebagai yang "layak," "suci," dan wajib dilakukan, maka sulit pula membayangkan adanya "rasa" yang menolak pembunuhan dan peperangan "suci."

Tetapi jika "nalar" kekerasan atas nama agama dan "tuhan" dianggap sebagai sesuatu yang tidak wajar dan tidak manusiawi, maka mudah juga membayangkan adanya "rasa" yang menolak kekerasan dan perang "suci" tersebut. Jika kondisi "nalar" dan "rasa" sudah menolak tindakan kekerasan atas nama agama dan "tuhan," maka orang didorong menyadari kekerasan sebagai sesuatu yang tidak menguntungkan dan akan beroleh semangat membangun budaya perdamaian.

Jika kesadaran tentang adanya nalar kekerasan dalam struktur sosial masyarakat telah terbentuk dan dibentuk dalam pertimbangan "nalar" dan "rasa" masyarakat, maka proses rekonsiliasi dapat berlanjut. Tanpa kesadaran seperti itu sulit membayangkan terjadinya proses rekonsiliasi yang sejati di tengah masyarakat. Dalam konteks masyarakat Halmahera, pernyataan sinis yang bisa muncul adalah apa gunanya sejumlah kesepakatan deklarasi damai, jika kesadaran internal tentang adanya "nalar" dan "rasa" kekerasan dalam struktur sosial tidak terbentuk? Mungkin secara eksternal orang dapat berspekulasi tentang rekonsiliasi, tetapi secara internal tidak mungkin terjadi.

Pertanyaannya adalah bagaimana mekanisme kritik diri itu dapat dilakukan? Robert J. Schreiter mengusulkan, sebaiknya tugas itu dimulai dari kelompok-kelompok kecil yang ada dalam jemaat yang bersifat profetis terhadap Gereja dan masyarakat. Kelompok-kelompok kecil yang dibentuk ini dalam hal tertentu harus mengambil jarak secara struktural dari organisasi jemaat, sehingga dapat mengkritisi segenap kebijakan yang diambil. ${ }^{13}$

13 Robert J. Schreiter, Rekonsiliasi Membangun Tatanan Masyarakat Baru. Terjemahan Biro Penerbit Provinsi SVD (Ende: Nusa Indah, 2000), hlm. 67-73. 
Menurut penulis, usulan ini baik, namun masih menemui sejumlah soal, yakni bagaimanakah satu kelompok kecil dapat membentuk dirinya lalu mengkritisi nalar kekerasan yang telah membentuk diri mereka? Siapakah yang harus mulai dan siapakah yang akan diajak bergabung?

Berkaitan dengan hal itu, Gerrit Singgih mengusulkan agar Gereja melakukan dua hal, yakni presensia dan dialog sebagai jalan keluar. Presensia adalah sikap yang tidak menjauhkan diri dari dunia, melainkan masuk ke dalam dunia, bergumul dengan segala konteks dan persoalan yang terjadi dalam dunia. Sedangkan dialog adalah sikap yang menghargai kebenaran sebagai sesuatu yang bukan milik sendiri. Kebenaran itu hanya ada pada Tuhan dan semua manusia yang beragama dipanggil untuk meyakini dan mempercayai kebenaran itu dengan cara dan metode yang bisa saja sama tetapi juga bisa berbeda. Dalam dialog semua orang, berdasarkan agamanya masing-masing, diajak untuk saling menghargai dan mengakui bahwa perbedaan adalah realitas yang tidak dapat ditolak. ${ }^{14}$

Menurut penulis, usulan itu pun masih menghadapi sejumlah persoalan, yakni bagaimana dapat membangun suatu teologi Gereja yang bebas dari nalar kekerasan sementara Gereja sendiri ada dalam nalar kekerasan itu? Menurut penulis, baik presensia maupun dialog jangan dianggap sebagai jalan keluar, melainkan sebagai hakikat dan eksistensi setiap orang; sebuah "jalan dari dalam." Kalau presensia dan dialog merupakan jalan keluar, maka presensia dan dialog adalah sesuatu yang berada di luar diri manusia yang dapat dilewati dan dilalui agar ia dapat keluar dari nalar kekerasan yang sedang melingkupinya. Tetapi, kalau presensia dan dialog adalah sesuatu yang menjadi hakikat dan eksistensi manusia, hal itu berarti bahwa kedua hal tersebut merupakan bagian yang berada di dalam diri manusia, yang melalui perwujudannya manusia akan terbebas dari nalar kekerasan yang melingkupinya.

Menurut penulis, eksistensi seperti itu sangat jelas terungkap dalam kesaksian Kitab Kejadian (Kej 2:8;15). Ayat 8 menegaskan: “Selanjutnya 14 Emanuel Gerrit Singgih, Mengantisipasi Masa Depan, hlm. 56-73. 
Tuhan Allah membuat taman di Eden, di sebelah Timur, di situlah ditempatkan-Nya manusia yang dibentuk-Nya itu." Ayat 15 menandaskan "Tuhan Allah mengambil manusia itu dan menempatkannya dalam taman Eden untuk mengusahakan dan memelihara taman itu."

Menarik untuk memperhatikan kata "taman Eden" dan frase "ditempatkan untuk mengusahakan dan memelihara." Bagi penulis, "taman Eden"15 dalam teks tersebut tidak dapat dipahami sebagai sebuah taman yang bagus, indah, serta tanpa masalah atau tanpa dosa seperti yang biasa dipahami selama ini, melainkan harus dipahami sebagai sebuah taman yang penuh dengan nalar kekerasan. Hal ini harus menjadi perhatian khusus, sebab justru di taman (Eden) itulah manusia jatuh ke dalam dosa, yakni ke dalam nalar kekerasan dan memberontak terhadap Allah (Kej 3). Manusia dalam konteks kejatuhan itu harus dipahami sebagai hasil dari pengaruh dan pembentukan nalar kekerasan yang merupakan sisi lain dari tatanan dan struktur sosial di taman Eden. Justru dalam konteks seperti itulah Allah "menempatkan manusia untuk mengusahakan dan memelihara taman itu," yaitu untuk mengusahakan dan memeliharanya dengan cara membangun perdamaian dan rekonsiliasi. Sudah barang tentu penempatan manusia ke dalam konteks itu harus dipahami sebagai unsur presensia dalam pemikiran Singgih, sehingga sekaligus manusia harus membangun dialog. Presensia dan dialog adalah pola hidup dan gaya hidup yang harus diejawantahkan oleh manusia di taman Eden berdasarkan kehendak Tuhan Allah.

15 Herbert Haag memperlihatkan bahwa kata Eden, dalam bahasa Ibrani (ay-den) berarti bahagia, seperti yang terdapat dalam Yeheskiel 31:9,16,18. Herbert Haag, Kamus Alkitab (Ende: Nusa Indah, 1992), hlm. 103-104. Sementara LXX dan Vulgata, menterjemahkan kata tersebut (ay-den) dengan kesenangan hati atau menyenangkan hati. Secara khusus dalam Yesaya 51:3, LXX menterjemahkannya dengan paradeisos yang berasal dari bahasa Persia pairidaeza yang berarti berpagar yang menunjuk pada taman atau halaman kesukaan. Kata inilah yang kemudian membentuk kata dalam bahasa Inggris paradise yang artinya firdaus atau surga. Herbert Haag, Ensiklopedi Alkitab Masa Kini. Jilid I (Jakarta: Yayasan Komunikasi Bima Kasih/OFM, 1992), hlm. 164-265. 


\section{Pusara Korban Sebagai Cerita Baru Yang Membebaskan}

Selain langkah kritik diri seperti yang telah dijelaskan di atas, menurut penulis, ada juga langkah kedua yang dapat dikerjakan oleh masyarakat di Halmahera dalam rangka membangun budaya damai di era pasca konflik. Langkah itu adalah-seperti yang dikemukakan oleh Robert Schreiter dalam bukunya ${ }^{16}$ - memanfaatkan realita dan budaya membangun pusara korban tindak kekerasan untuk menjadi "sumber daya" dalam membentuk dan membangun cerita-cerita baru yang membebaskan masyarakat dan keluarga korban dari akibat tindak kekerasan. ${ }^{17}$ Pertanyaannya adalah dalam hal apakah realita pusara korban itu dapat dimanfaatakan untuk membangun budaya perdamaian? Mengacu pada pendapat Schreiter, penulis mencatat enam hal berikut.

\section{Makna Ritual di Salabe: Keluarga Sebagai Komunitas Basis Rekonsiliasi}

Selain sebagai tempat meletakkan jasad orang mati, salabe juga dimanfaatkan untuk kegiatan ritual dalam keluarga. Pelaksanaan ritual dalam tradisi salabe sangat membutuhkan peranan kepala keluarga yang bertindak sebagai pemimpin upacara. Jika kepala keluarga tidak dapat menjalankan tugasnya, maka salah seorang yang paling tua dalam

16 Robert J. Schreiter, Rekonsiliasi Membangun Tatanan Masyarakat Baru ((Ende: Nusa Indah, 2000).

17 Hal yang sama juga dikemukakan oleh R. Scott Appleby ketika berbicara mengenai tipologi transformasi konflik secara religius. Appleby menegaskan bahwa upaya transformasi konflik secara religius mencakup bukan hanya transformasi dan perubahan struktur pasca konflik, tetapi juga usaha-usaha yang dilakukan oleh segenap elemen masyarakat, para ahli teologi, aktor-aktor perdamaian, dan lain-lain, yang dirahkan kepada penciptaan struktur masyarakat yang nir-kekerasan. Menurut Appleby, hal yang demikian itu merupakan a sine qua non, suatu hal yang sangat fundamental bagi setiap agama yang ada dalam masyarakat. Appleby menegaskan bahwa dalam rangka memacu sebuah pembaruan struktural (structural reform) perlu adanya upaya-upaya membangun institusi dan praktik-praktik religius lokal dalam konteks sebuah masyarakat yang cocok bagi upaya perdamaian dan relasi tanpa kekerasan. Appleby menegaskan hal ini berdasarkan pengalaman tentang peranan agama (komunitas beragama) dalam upaya mentransformasikan konflik di Filipina, Yugoslavia, Afganistan, dan lain-lain, pada beberapa tahun belakang ini. R. Scott Appleby, The Ambivalence of The Sacred: Religion, Violence, and Reconciliation (Lanham: Rowman \& Litlefield, 2000), pp. 211-244. 
keluarga harus menggantikan peran kepala keluarga yang berhalangan. Tanpa peranan dari keluarga sendiri, ritual dalam tradisi salabe tidak dapat berjalan. ${ }^{18}$

Dalam hal ini tradisi salabe sangat membutuhkan peranan dan fungsi keluarga dalam rangka menjalankan acara ritual. Secara etis Kristiani, tanggung jawab sebagai keluarga Kristiani dapat dijalankan secara pribadi maupun secara bersama. Hal itu dapat dilakukan baik dalam bentuk kegiatan-kegiatan ritual, diakonal, dan sosial, yang sekaligus merupakan panggilan dan kesaksian terhadap sesama dan dunia sekitar.

Menurut Schreiter, peranan keluarga dalam rekonsiliasi justru menjadi kerygma yang tidak hanya membawa sukacita, tetapi juga membawa tawaran baru bagi perubahan struktur masyarakat. Melalui praktik hidup yang ditampilkan oleh keluarga-keluarga Kristen berdasarkan Injil Yesus Kristus, maka hal itu akan membawa pengaruh terhadap pola hidup atau gaya hidup masyarakat yang ada di sekitarnya. Struktur masyarakat yang lama-yang di dalamnya tersimpan segala kebusukan dan kekerasan-akan ditantang untuk berubah dan berorientasi pada struktur masyarakat yang baru; struktur masyarakat tanpa kekerasan. ${ }^{19}$

Dengan demikian, dapat dikatakan bahwa dalam tradisi salabe terkandung unsur dasar dalam membangun rekonsiliasi, yakni keluarga sebagai komunitas basis rekonsiliasi.

\section{Makna Ritual di Wonge: Perlunya Gerakan Masyarakat Warga Membantu ReKonsiliasi}

Ritual yang dilakukan di Wonge adalah ritual gomahate, yakni upacara pemanggilan "roh leluhur" yang akan hadir secara personifikasi melalui pemimpin upacara. Melalui ritual gomahate pemimpin upacara akan melakukan dialog dengan arwah leluhur untuk menentukan siapa

18 S. Kutjame, "Pengaruh Agama Asli dalam Kehidupan Gereja Masehi Injili di Halmahera," dalam H.G. Schuurman, ed., Seri Sejarah GMIH no 5 (Tobelo: STT GMIH, 1995), hlm. 10-11.

19 Robert J. Schreiter, Rekonsiliasi: Membangun Tatanan Masyarakat Baru, hlm. 47. 
penyebab dari segala malapetaka yang telah terjadi. Ketika dialog dalam ritual gomahate berhasil menunjuk "sang pelaku" yang dianggap penyebab malapetaka dalam masyarakat, maka orang tersebut harus dihanyutkan di sungai dan kadangkala dibunuh agar ada keharmonisan dalam masyarakat. ${ }^{20}$

Dalam pandangan Girard, pola hidup seperti itu telah membongkar rahasia asal-usul kekerasan dalam masyarakat. Melalui praktik pengharmonisasian kehidupan masyarakat sebenarnya masyarakat selalu dituntut untuk melakukan kekerasan secara legal, yaitu kekerasan semua melawan satu. Girard menyebutkan proses ini sebagai "mekanisme kambing hitam." Dalam hal ini “korban” yang dijadikan sebagai "kambing hitam" telah berfungsi sebagai sarana substitusi dalam penyaluran atau pengosongan kekerasan yang dilakukan dengan kekerasan pula. ${ }^{21}$

Memperhatikan pemikiran tersebut, menurut penulis, proses "mekanisme kambing hitam" tampaknya juga telah terjadi dalam konflik di Halmahera antara 1999-2000, yang penulis sebut dengan istilah "mekanisme kambing hitam keagamaan." Dalam hal ini para "korban" yang telah dimakamkan di pusaranya masing-masing, telah dianggap sebagai "sang pelaku" "kekafiran" dan orang-orang "sesat" yang wajar dikorbankan demi kesucian dan kemurnian agama. Hal pengkambinghitaman keagamaan seperti ini, menurut penulis, harus disadari oleh masyarakat di Halmahera, bahkan di Indonesia, dalam rangka membangun rekonsiliasi dan budaya tanpa kekerasan, sehingga sikap dan kecenderungan menganggap orang lain yang berbeda agama sebagai "kafir" dan "sesat" dapat dieleminasikan dan dihilangkan.

Dalam konteks masyarakat Halmahera, menurut penulis, kesadaran seperti itu hanya dapat diperoleh, jika realita pusara korban bisa dijadikan sebagai sarana untuk membangun kesadaran masyarakat bahwa jika kekerasan dilawan dengan kekerasan akibatnya adalah sejumlah

20 S. Kutjame, "Pengaruh Agama Asli," hlm. 24

21 Sindhunata, Kambing Hitam, hlm. 98-106. 
pusara korban yang lebih banyak. Dalam hal ini pusara korban harus menjadi tanda awas bagi masyarakat yang terkungkung dalam budaya mekanisme kambing hitam keagamaan dan praktik kekerasan.

Pengalaman kekerasan pada 1999-2000 harus menjadi inspirasi dan motivasi bagi masyarakat untuk membangun gerakan masyarakat warga (civil society) guna memberdayakan struktur sosial masyarakat yang bebas dari praktik mekanisme kambing hitam keagamaan dan budaya kekerasan atas nama agama dan atas nama "tuhan," yaitu dengan mengedepankan nilai-nilai kebebasan, toleransi, perdamaian, dan kemanusiaan dalam hidup bersama. ${ }^{22}$

\section{Ritual di Pusara Korban: Modus Pengobatan Luka-luka Batin}

Masyarakat Halmahera sering melakukan sejumlah aktivitas di sekitar pusara korban; seperti berziarah, mengadakan doa pergumulan, mengobati rasa rindu, meringankan beban hidup, menyelesaikan persoalan yang sedang dihadapi, menyatakan dan membangun tekad hidup, bahkan ada yang datang untuk memohon agar berhasil dalam perjuangan hidup.

Menurut Schreiter, kegiatan seperti itu dapat membantu para korban kekerasan untuk menemukan dirinya sebagai orang-orang yang terluka, yang merupakan syarat utama memasuki proses penyembuhan luka-luka itu. ${ }^{23}$ Lisa Schirh menegaskan bahwa dalam ritual seperti itu terdapat kesempatan bagi para korban kekerasan untuk melihat kemanusiaan mereka dan kemanusiaan para pelaku kekerasan. ${ }^{24}$

22 Penegasan tersebut penulis kutip dari pernyataan J.B. Banawiratma ketika berbicara tentang "Tiga Poros Kekuasaan dalam realitas publik" dalam mata kuliah "Gereja dalam konteks Indonesia," pada Program Pasca Sarjana Teologi, Universitas Kristen Duta Wacana, Yogyakarta, Kamis, 20 September 2007. Menurut Banawiratma, ketegangan bahkan konflik yang sering terjadi dalam masyarakat sangat dipengaruhi oleh penyelewengan kekuasaan yang dilakukan oleh negara, pasar, dan komunitas (Tiga Poros Kekuasaan). Maka untuk keluar dari ketegangan dan konflik tersebut, peranan dari gerakan civil society sangat penting dan menentukan.

23 Robert J. Schreiter, Rekonsiliasi, hlm. 77-83.

24 Lisa Schirh, "Ritual Reconciliation: Transforming Identity/Reframing Conflict," in Reconciliation Justice and Coexistence: Theory and Practice, edited by Mohammed AbuNimer (Lanham: Lexington Books, 2001), p 147. 
Pengungkapan diri sebagai orang yang terluka kadangkala memang sulit, karena hal semacam itu sering dipahami sebagai bentuk dari kelemahan manusia. Tetapi itulah syarat untuk menyembuhkan lukaluka batin. Paulus S. Widjaja menegaskan bahwa sesuatu yang lebih manusiawi dalam diri para korban kekerasan hanya dapat diperoleh jika para korban menyadari dirinya sebagai orang-orang yang terluka dan bersedia mengungkapkan luka-luka itu secara tegas dan gamblang. ${ }^{25}$

Pertanyaannya, bagaimana hal itu dilakukan? Pengungkapan diri sebagai orang-orang yang terluka sebenarnya dapat dilakukan jika ada kesadaran dalam diri setiap orang bahwa ia adalah makhluk yang sangat rentan atau rawan terhadap akibat yang disebabkan oleh tindak kekerasan. Ia sebenarnya tidak mempunyai kekuatan apa-apa jika dihadapkan dengan realita dan tindak kekerasan. Ia adalah makhluk yang sangat mudah dihancurkan oleh tindak kekerasan.

Realita pusara korban itulah bukti kerentanan, kerawanan, dan kegampangan hancurnya manusia jika berada dalam dunia kekerasan. Jika ia melawan kekerasan dengan kekerasan - sebagai gambaran bahwa ia bukan makhluk yang rentan, rawan, dan gampang dihancurkan oleh kekerasan - akibatnya adalah pusara korban. Realita pusara korban adalah lambang kesombongan manusia yang tidak mau mengakui kerentanan, kerawanan, dan kegampangan dirinya ketika dirasuki oleh nilai-nilai kekerasan. Kekerasan akan berakibat pada kematian dan pusara korban, sedangkan kematian dan pusara korban adalah lambang

25 Paulus S. Widjaja, “Rekonsiliasi Antar Umat Beragama: Refleksi Pengalaman Lapangan” dalam Perempuan, Konflik dan Rekonsiliasi: Perspektif Teologi dan Praksis, diedit oleh B. D. Putrianti dan A. N. Natar (Yogyakarta: PSF UKDW, 2006), hlm. 67-73. Hal yang senada dikemukakan juga oleh Sigmund Freud dalam teori psikoanalisisnya, yaitu bahwa penanganan masalah traumatik dan luka batin setiap orang hanya dapat dilakukan dengan cara penjelajahan dunia pengalaman tak-sadar ke dalam pengalaman kesadaran orang tersebut. Freud menyebutkan proses seperti ini merupakan bagian dari prinsip kesenangan (pleasure principle), yaitu sebuah proses dinamis yang terjadi secara alamiah dalam diri seseorang untuk membantu dirinya sendiri supaya keluar dari beban-beban traumatiknya. Dalam Sigmund Freud, A General Introduction To Psychoanalysis (Pengantar Umum Psikoanalisis), terj. \& penyunting Haris Setiowati, (Yogyakarta: Pustaka Pelajar, 2006), hlm. 524. 
bahwa ia (manusia) adalah makhluk yang melawan eksistensinya yang rentan, rawan, dan gampang dihancurkan oleh kekerasan itu.

Unsur-unsur seperti itulah yang harus dimaknai oleh masyarakat Halmahera dalam setiap aktivitas yang dilakukan di sekitar pusara korban. Tanpa menyertakan unsur-unsur seperti itu dalam setiap aktivitas dan ritual di sekitar pusara korban, dapat terjadi bahwa segala aktivitas di sekitar pusara korban akan menjurus pada pembentukan kebencian dan niat untuk melakukan balas dendam dari generasi ke generasi. Pengungkapan diri sebagai manusia yang sangat rentan, rawan, dan gampang dihancurkan oleh kekerasan merupakan dasar untuk mengobati luka-luka batin yang sedang dialami oleh masyarakat.

\section{Salib Sebagai Lambang Penderitaan, Rekonsiliasi, dan Perdamaian}

Realitas simbolik yang umumnya terdapat di pusara korban adalah salib. Dalam kesaksian Alkitab, makna salib sebenarnya tidak berhenti pada penderitaan dan kematian, melainkan berlanjut pada kebangkitan dan hidup baru. Kalau salib hanya bermakna penderitaan dan kematian, maka kesaksian tentang Yesus pun akan berhenti dan selesai pada kayu salib. Tetapi, Alkitab memberi kesaksian yang lain; setelah penderitaan dan kematian, Yesus bangkit dan memperoleh hidup baru. Makna salib masih berlanjut, tidak berhenti pada penderitaan melainkan melampauinya dan menghadirkan kehidupan baru.

Di sini salib sekaligus menjadi jalan datangnya kehidupan baru. Karya Yesus seperti itulah yang hendak dijelaskan oleh rasul Paulus dalam Efesus 2:12-16 dan Kolose 1:19-20. Kata "memperdamaikan" dan "pendamaian" dalam Kolose 1:20 ditulis dengan kata Yunani apokatallaxai yang berarti memperdamaikan, ${ }^{26}$ dan kata eirenopoietas yang berarti pendamaian. ${ }^{27}$ Kata apokatallasso - yang berarti memperdamaikan dalam teks ini dipakai dalam rangka menjelaskan proses rekonsiliasi, sedangkan kata eirenopoietas - yang berarti pendamaian-digunakan

26 Hasan Sutanto, Perjanjian Baru Interlinear Yunani-Indonesia dan Korkondansi Perjanjian Baru, Jilid II. (Jakarta: Lembaga Alkitab Indonesia, 2006), hlm. 100.

27 Hasan Sutanto, Perjanjian Baru Interlinear Yunani-Indonesia, hlm. 246. 
dalam rangka menjelaskan keadaan atau kondisi yang penuh damai dan sejahtera (eirene) sebagai akibat dari proses rekonsiliasi. Intinya, melalui apokatallasso terciptalah eirenopoietas, dan eirenopoietas itu tercipta justru karena peristiwa salib.

Dalam era pasca konflik dan dalam upaya membangun perdamaian, makna salib seperti itu sangatlah penting. Bahkan harus dikatakan jika salib hanya dimaknai sebagai lambang penderitaan, hal itu belum mewakili makna salib yang sesungguhnya. Salib yang dipersaksikan oleh Alkitab adalah salib yang bermakna selain penderitaan, juga rekonsiliasi dan perdamaian. Bukan saja rekonsiliasi dan perdamaian dengan Allah, melainkan juga dengan sesama dan seluruh kosmos. Menurut penulis, jika makna salib sebagai rekonsiliasi dan perdamaian itu dibawa ke konteks masyarakat Halmahera, maka makna yang harus ditekankan adalah salib sebagai lambang rekonsiliasi dan perdamaian di antara manusia yang beragama Kristen dan Islam.

\section{Martir Sebagai Pemutus Rantai Kekerasan}

Dalam tradisi Kristen, referensi martir biasanya bersumber dari kisah Stefanus, seorang murid Yesus yang mati "syahid" karena imannya kepada Yesus Kristus (Kis. 6:8-7:60). Kata "martir" juga dapat ditemukan dalam pernyataan seorang Bapa Gereja yang terkenal pada abad I yakni Tertulianus: "Darah para martir adalah benih bagi Gereja." 28 Tetapi, jika kita memperhatikan penggunaan kata "martir" dalam dua kisah itu (Stefanus dan Tertulianus) ternyata kata tersebut mempunyai konteks dan makna yang berbeda.

Berdasarkan alur cerita dalam Kisah Para Rasul (Kis 6:8-7:60), menurut penulis, ada beberapa hal yang perlu digaris bawahi dalam rangka memahami Stefanus sebagai seorang martir. Pertama, konteks persoalan yang dihadapi Stefanus adalah konteks hasutan dan dusta

28 F. D. Welem, Riwayat Hidup Singkat Tokoh-tokoh Dalam Sejarah Gereja (Jakarta: BPK Gunung Mulia, 2003), hlm. 179-180. 
orang-orang Libertini ${ }^{29}$ yang berhasil mempengaruhi para pemimpin Yahudi. Mereka ini berhasil mempengaruhi para pemimpin Yahudi dengan hasutan dan dusta. Kedua, hasutan dan dusta itu berkaitan dengan masalah adat istiadat atau hukum Taurat. Ketiga, pembelaan Stefanus sebagian besar adalah meyakinkan asal-usul bangsa Israel sejak Abraham hingga Yesus Kristus yang telah mati dan bangkit. Keempat, ternyata ketiga hal itu - atau lebih tepat lagi kisah itu-dipakai oleh penulis kitab untuk menjelaskan peranan Roh Kudus bagi keberadaan Jemaat Kristen (bukan Yahudi) yang pada waktu itu sedang mengalami banyak penderitaan yang diakibatkan oleh perlakuan orang-orang Yahudi. Dapat dikatakan bahwa konteks Stefanus adalah konteks perseteruan dan permusuhan.

Dalam konteks seperti itu terdapat satu hal yang menarik dari kisah Stefanus yang perlu kita perhatikan, sebagaimana tertulis dalam Kitab Kisah Para Rasul: "Sambil berlutut ia berseru dengan suara nyaring: “Tuhan, janganlah tanggungkan dosa ini kepada mereka! Dan dengan perkataan ini meninggallah ia." ${ }^{30}$ Tentu ayat ini menggambarkan sebuah kondisi yang sungguh-sungguh penuh derita dan sakit yang luar biasa. Stefanus dengan jujur mengungkapkan apa yang ia rasakan dan alami itu, baik secara fisik (berlutut) maupun psikis (lewat suara yang keras). Tetapi yang mengagumkan, ia tidak menaruh dendam kepada para pelaku kekerasan karena derita dan rasa sakit itu, melainkan hal itu disampaikan kepada Tuhan agar Tuhan mengampuni mereka. Di sinilah letaknya konsep penting dari Stefanus sebagai seorang "martir," yaitu seorang yang mati syahid, tetapi tidak membalas kekerasan dengan kekerasan melainkan dengan permohonan pengampunan.

Sementara kata yang sama (martir) yang dipakai oleh Tertulianus justru mempunyai konteks dan makna yang berbeda dengan pengertian tersebut. Menurut F.D. Welem, kata "martir" dalam penggunaan

29 Libertini berarti “Orang bebas," yaitu orang Yahudi atau keturunan mereka yang dulunya hamba tetapi sekarang telah dibebaskan. Hasan Sutanto, Perjanjian Baru Interlinear Yunani-Indonesia, hlm. 486.

30 Kis 7:60. 
Tertulianus lebih mengarah kepada penggunaan kekerasan untuk membela ajaran Gereja dan melarang orang menjadi murtad. Pembelaan terhadap ajaran Gereja dan larangan menjadi murtad adalah kebajikan yang tertinggi dalam pandangan Tertulianus. Oleh karena itu, setiap orang Kristen harus bersedia menjadi syahid (martir) karena hal itu adalah sesuatu yang mulia. ${ }^{31}$

Dapat dikatakan bahwa kara "martir" dalam kisah Stefanus lebih berorientasi pada akibat yang diterima oleh seseorang karena tidak melawan kekerasan dengan kekerasan, sedangkan pada kisah Tertulianus kata "martir" adalah tujuan yang harus dicapai oleh seseorang dalam kehidupannya. Menjadi martir karena akibat dan menjadi martir karena tujuan pasti berbeda; yang pertama lebih bersifat pasif (menjadi korban), yang kedua lebih bersifat aktif bahkan agresif (mengorbankan diri sendiri ataupun mengorbankan orang lain).

Tampaknya pengertian yang kedua inilah yang telah mendominasi pemaknaan kata "martir" (syuhada) di kalangan masyarakat Halmahera untuk para korban. Menurut Jon Sobrino, pemaknaan "martir" seperti itu adalah sesuatu yang bertentangan dengan upaya-upaya mengatasi kekerasan dan membangun perdamaian. Untuk keluar dari persoalan itu dan untuk membantu masyarakat pasca konflik memandang para korban sebagai orang-orang yang telah berjuang di tengah realitas kekerasan yang sadis dan kejam itu, menurut Sobrino, para martir harus dipahami sebagai

.....orang-orang yang telah mengambil kekerasan dan dosa-dosanya untuk diri mereka sendiri. Dan akhirnya kita harus mengatakan bahwa mereka adalah orang-orang yang telah banyak berjasa mempercepat berakhirnya kekerasan. Martir-martir (para syuhada) ini adalah mereka yang membawa pengampunan ke dalam masyarakat yang mementingkan diri sendiri; mereka yang membawa rekonsiliasi ke dalam masyarakat korban dan algojo; mereka yang membawa keadilan dan perdamaian ke

31 F. D. Welem, Riwayat Hidup Singkat Tokoh-tokoh Dalam Sejarah Gereja, hlm. 180. 
dalam masyarakat yang tidak adil; masyarakat kekerasan yang terlembagakan. ${ }^{32}$

\section{Mati Dalam Nama Tuhan dan Mati Atas Nama Tuhan}

Pada umumnya orang tidak dapat membedakan mati dalam nama Tuhan dan mati atas nama Tuhan, karena keduanya sama-sama disemangati dan didasarkan pada keyakinan dan iman kepada Tuhan; mati dalam nama Tuhan dan yang mati atas nama Tuhan, semuanya untuk Tuhan. Namun sesungguhnya kedua hal itu berbeda, baik dalam motivasinya maupun dalam kualitasnya.

Dari sudut motivasi, mati dalam nama Tuhan berkaitan erat dengan sebuah kehidupan, sedangkan mati atas nama Tuhan (kadang-kadang juga bisa berarti mati seperti Tuhan ${ }^{33}$ ) berkaitan erat dengan sebuah kematian. ${ }^{34}$ Mengapa? Orang yang mati dalam nama Tuhan adalah orang yang menyerahkan diri sepenuhnya dan taat kepada karya dan kehendak Tuhan, sedangkan orang yang mati atas nama Tuhan (kadangkala seperti Tuhan) adalah orang yang memaksakan karya dan kehendak dirinya untuk ditaati Tuhan.

Memang semuanya akan mati, tetapi yang mati dalam nama Tuhan akan menerima kehidupan yang telah disediakan oleh Tuhan sesuai dengan rencana-Nya. Tetapi orang yang mati atas nama Tuhan (seperti

32 Jon Sobrino, "Agama dan Kekerasan: Masalah dan Pemecahan kasus Amerika Latin: Guatemala/El-Savador," dalam Agama Sebagai Sumber Kekerasan?, disunting oleh Wim Beuken dan Karl-Josef Kuschel, et al., terj. Imam Baehaqie (Yogyakarta: Pustaka Pelajar, 2003), hlm. 86.

33 Misalnya orang-orang di Philipina yang bersedia disalibkan pada setiap tahun dalam perayaan kematian dan kebangkitan Yesus demi untuk meniru cara kematian Yesus di kayu salib.

34 Lawrence Yoder-dalam makalahnya "Kekristenan Yang Akan Datang di Indonesia, Visi, Bentuk, dan Komitmennya, Bakal Bagaimana?" yang disampaikan pada seminar sehari tentang “Will There Be The Next Christendom?" di Universitas Kristen Duta Wacana, Yogyakarta, pada 2 April 2008, hlm.18-memaparkan bahwa mati atas nama Tuhan merupakan suatu bentuk dari sikap ekstrimisme dalam mental keagamaan yang dapat mendukung nilai-nilai kekerasan atas nama agama dan atas nama "tuhan." Pengalaman itu nyata sekali pada zaman perang Salib. Lihat juga pemikiran Abdul Munir Mulkan dalam makalahnya tentang "Persepsi Muslim Terhadap Aksi-aksi Sosial Kristiani" yang disampaikan pada seminar yang sama, hlm.5-6. 
Tuhan), mengalami kematian. Hal itu terjadi dalam sebuah keterpaksaan dan berada di luar karya dan kehendak Tuhan. Oleh karena itu, mereka yang mati dalam Tuhan berhubungan dengan kehidupan, sedangkan mereka yang mati atas nama Tuhan (seperti Tuhan) berhubungan dengan kematian. Di sinilah letak kualitas dari masing-masing; mati dalam nama Tuhan berkualitas kehidupan, sedangkan mati atas nama Tuhan (seperti Tuhan) berkualitas kematian. "Kematian" yang penulis maksudkan adalah kematian yang sia-sia, sedangkan "kehidupan" adalah kematian yang tidak sia-sia.

Sampai di sini penulis harus menegaskan bahwa dengan berpikir seperti itu bukan berarti penulis sedang menghakimi apa yang telah terjadi dengan kematian para korban dalam peristiwa konflik di Halmahera, melainkan lebih menekankan apa yang harus dipahami (dimaknai) oleh orang-orang yang masih hidup, yang pernah terbebas dari kematian akibat konflik tersebut. Bagi penulis, perkara orang yang sudah mati tidak mungkin lagi bisa dibahas, tetapi perkara orang yang masih hidup masih terbuka untuk dibahas. Bukankah orang yang masih hidup adalah orang-orang yang harus akan mati? Oleh karena itu, ketika kita berbicara tentang kematian selagi masih hidup, hal itu sama artinya dengan berbicara tentang makna kehidupan itu sendiri.

Berkaitan dengan pemikiran seperti itu, menurut penulis, dua ayat Alkitab sebagaimana tertulis pada batu nisan pusara korban (Dokulamo dan Makete), yakni "Berharga di mata Tuhan kematian semua orang yang dikasihi-Nya (Mzm. 116:15)," dan “Bagiku hidup adalah Kristus dan mati adalah keuntungan (Filipi 1:21)" juga mendapatkan maknanya yang baru.

Dalam catatan Glandion Carney dan William Long, teks Mazmur 116:15 tersebut sebenarnya tidak berbicara tentang mati atau kematian itu sendiri, melainkan berbicara tentang pemahaman dan keyakinan terhadap peristiwa kematian. Bahkan pemahaman dan keyakinan tentang kematian yang ditekankan dalam teks tersebut, menurut mereka, adalah pemahaman dan keyakinan yang justru memberi arah kepada 
karya Allah yang dapat membebaskan orang dari belenggu kematian. Belenggu kematian yang dimaksudkan adalah belenggu kebinasaan dan kesia-siaan, sedangkan karya pembebasan Allah yang dimaksudkan di sini ialah karya kasih-Nya yang besar yang melampaui belenggu kematian. Manusia memang bisa, dan harus, mati atau mengalami kematian, tetapi kematian manusia yang terjadi dalam kasih Allah adalah kematian yang sudah dibebaskan dari belenggu kematian, dalam arti bebas dari kebinasaan dan kesia-siaan. ${ }^{35}$

Dalam pemikiran penulis, konsep seperti inilah yang dimaksudkan dengan kematian dalam nama Tuhan, kematian yang bebas dari belenggu kematian, kematian yang berkualitas kehidupan. Tetapi kematian dalam kasih Allah seperti itu, tidak terjadi secara netral dan otomatis tanpa adanya respon dari manusia. Menurut Carney dan Long, respon manusia terhadap kasih Allah yang membebaskan kematian dari belenggu kematian itu, juga harus terwujud dalam kasih di antara sesama dan kasih kepada Allah. ${ }^{36}$

Menurut penulis, hal yang senada dengan itu juga ditekankan oleh rasul Paulus dalam suratnya kepada jemaat di Filipi (Fil 1:21): “Bagiku hidup adalah Kristus dan mati adalah keuntungan." William Barclay memperlihatkan bahwa ungkapan sang rasul dalam ayat tersebut juga berhubungan dengan suatu konteks keterbelengguan, yakni upaya untuk membelenggu Injil Yesus Kristus yang sedang diberitakan oleh sang rasul. Menurut Barclay, pokok penting dalam perikopa ini terletak pada pemahaman dan keyakinan sang rasul tentang Injil Yesus Kristus yang tidak dapat terbelenggu. Dengan mengungkapkan bahwa “Bagiku hidup adalah Kristus dan mati adalah keuntungan," ${ }^{37}$ sang rasul telah sungguhsungguh memahami bahwa sekalipun ia akan mati dibunuh (kalau hal itu yang akan terjadi), Injil Yesus Kristus tidak dapat dibelenggu oleh siapa pun juga. Kematian Paulus sama sekali tidak membawa kerugian

35 Glandion Carney \& William Long, Longing For God: Prayer \& the Rhythms of Life (Downers Grove, IL: Intervarsity Press, 1993), pp. 184-189.

36 Glandion Carney \& William Long, Longing For God, p. 189.

37 Ayat ini dikutip pada batu nisan pusara korban di desa Makete. 
("mati adalah keuntungan") terhadap pemberitaan Injil Yesus Kristus. Injil Yesus Kristus tidak tergantung semata-mata pada seorang Paulus, melainkan tergantung pada semangat pemberitaan umat atau jemaat yang sudah mengalami kasih Kristus. Kasih Kristus jauh lebih besar kuasanya dari pada segenap kuasa pembelengguan terhadap Injil tersebut. Tetapi kenyataan itu seolah-olah akan lebih lancar lagi jika Paulus tidak jadi mati dibunuh. Inilah makna ungkapan "bagiku hidup adalah Kristus." 38

Intinya, teks Mazmur 116:15 dan Filipi 1:21 sebenarnya tidak hanya berbicara tentang kematian pada dirinya sendiri, tetapi yang lebih utama adalah tentang kehidupan. Bahkan kematian yang dibicarakan dalam kedua ayat tersebut justru diarahkan kepada bentuk tanggung jawab dan panggilan yang harus diejawantahkan oleh manusia dalam kehidupannya sebelum mengalami kematian. Tanpa melakukan tanggung jawab dan panggilan tersebut dalam kehidupannya, maka kematian yang akan dialami oleh manusia adalah kematian yang tidak bermakna kehidupan. Perwujudan tanggung jawab dan panggilan itu begitu penting bagi manusia dalam kehidupannya demi kematiannya yang berkualitas kehidupan di dalam kasih Allah. Ini berarti bahwa kedua teks tersebut sebenarnya mengandung perintah kepada manusia untuk mengisi kehidupan sebelum kematian, yakni dengan sikap saling mengasihi sebagai respon atas kasih Allah yang telah membebaskannnya dari belenggu kematian.

Berdasarkan pemikiran seperti itu, maka menurut penulis pemaknaan kedua ayat yang telah diletakkan pada batu nisan pusara korban tersebut (di Dokulamo dan Makete) jangan hanya dimaknai oleh para korban saja, melainkan harus dimaknai juga untuk orang-orang yang meletakkannya. Orang-orang yang masih hidup perlu segera mengisi kehidupannya dengan membangun sikap saling mengasihi sebagai respon atas kasih Allah yang telah membebaskan mereka dari belenggu kematian yang mengerikan dan menakutkan itu.

38 William Barclay, Pemahaman Alkitab Setiap Hari: Surat Filipi, Kolose, 1 dan 2, Tesalonika, terj. Ferdy Suleeman (Jakarta: BPK Gunung Mulia, 2006), hlm. 36-49. 
Dalam pemahaman seperti itu, kata dodara (artinya: cinta, kasih) yang dipakai sebagai nama lokasi pusara korban di desa Duma memperoleh maknanya secara lebih mendalam. Dalam bahasa Galela selain kata dodara yang berarti cinta atau kasih, ada juga kata lain yang mengandung arti yang sama, yaitu kata galusiri. Tetapi umumnya kata galusiri dipakai untuk menunjukkan hubungan cinta atau kasih di antara manusia, sedangkan kata dodara digunakan untuk menunjukkan hubungan cinta atau kasih antara Allah dengan manusia.

Dari uraian di atas, pemakaian kata dodara pada lokasi pusara korban tersebut jangan hanya dimaknai sebagai wujud kasih Allah kepada para korban, melainkan juga sebagai bentuk pemahaman bahwa kematian di dalam nama Tuhan adalah kematian yang terbebas dari belenggu kematian. Selanjutnya, berdasarkan pemahaman itu, kasih dalam pengertian galusiri-pun penting untuk diejawantahkan dalam kehidupan sehari-hari. Kasih dalam bentuk dodara dan kasih dalam bentuk galusiri adalah kasih yang saling berhubungan. Dapat dikatakan, karena adanya dodara maka galusiri harus diwujudkan dalam kehidupan setiap hari. Dodara harus menjadi dasar semangat bagi perwujudan galusiri. Dodara akan bermakna jika terlihat dalam galusiri, sebaliknya galusiri akan terasa kosong dan terpaksa jika tanpa dodara. Nama lokasi pusara korban di desa Duma itu harus menjadi motifasi bagi masyarakat untuk memberlakukan galusiri dalam kehidupan setiap hari sebagai wujud respon kepada dodara; karena dodara maka masyarakat yang beragama Kristen dan Islam harus melakukan galusiri dalam kehidupan mereka setiap hari.

\section{PENUTUP}

Demikianlah beberapa catatan yang telah penulis kerjakan untuk memberi sumbangan pemikiran bagi proses transformasi diri masyarakat di Halmahera dalam kerangka membangun budaya damai di sekitar pusara korban. Berikut ini beberapa catatan kesimpulan yang bersifat rekomendatif untuk dipikirkan dan ditindaklanjuti. 
Pertama, pembangunan pusara korban di halaman rumah ibadah pada dasarnya telah dilatari oleh tradisi masyarakat yang berhubungan dengan kecenderungan memelihara jasad orang-orang yang dianggap berjasa dalam masyarakat.

Kedua, penghayatan masyarakat terhadap realita tersebut ternyata dapat mengandung arti negatif bagi upaya membangun rekonsiliasi dan perdamaian.

Ketiga, apabila pemahaman masyarakat tentang realita pusara korban itu dapat ditransformasikan dan dihayati sebagaimana yang telah penulis upayakan dalam artikel ini, maka realita pusara korban dapat bermanfaat dan mengandung makna yang positif bagi upaya rekonsiliasi dan perdamaian di Halmahera.

Keempat, bagaimana transformasi diri seperti itu dapat dilakukan? Menurut hemat penulis ada tiga hal yang harus diperhatikan.

Pertama, memaksimalkan kegiatan-kegiatan dalam kelompok tani, kelompok perikanan, dan kelompok kerja gotong royong yang telah terbentuk dalam masyarakat dengan melakukan kegiatan-kegiatan yang berorientasi pada hal-hal yang berkaitan dengan pemberdayaan manusia dan pemberdayaan struktural yang menunjang proses rekonsiliasi dan perdamaian. Kegiatan-kegiatan tersebut, misalnya, membuat dan menyediakan mekanisme penyelesaian konflik dalam aras kelompok dengan cara menetapkan badan pengurus kelompok yang berfungsi menangani masalah konflik; melakukan kegiatan-kegiatan pelatihan atau pembinaan tentang perdamaian dan rekonsiliasi; melibatkan pihak ketiga yang bertindak sebagai fasilitator untuk kegiatan-kegiatan pendidikan perdamaian dan rekonsiliasi; serta melibatkan para ketua kelompok atau badan pengurus inti dalam setiap kelompok dalam upaya mewujudkan perdamaian dan melakukan rekonsiliasi ketika ada persoalan dalam kelompok. Semuanya itu dilakukan dalam rangka mensosialisasikan konsep-konsep transformasi pemaknaan dan pemahaman masyarakat terhadap realita pusara korban kepada orangorang yang masih hidup. 
Kedua, dalam konteks hidup menggereja (Gereja Masehi Injili di Halmahera) hal itu dapat dilakukan dengan cara menyediakan bahanbahan pengajaran bagi Sekolah Minggu, katekisasi, pemahaman Alkitab, dan khotbah dengan unsur-unsur yang berkaitan dengan rekonsiliasi dan perdamaian. Memadukan bahan-bahan itu dengan konsep-konsep yang berkaitan dengan nilai-nilai transformasi pemahaman masyarakat terhadap realita pusara korban, guna disosialisasikan kepada seluruh warga Gereja. Menetapkan Minggu atau Bulan penghayatan khusus untuk rekonsiliasi dan perdamaian. Merumuskan mekanisme penyelesaian konflik yang dikembangkan dalam Gereja sebagai bentuk pelayanan terhadap umat dengan cara membentuk bidang pelayanan khusus untuk rekonsiliasi dan perdamaian, baik di tingkat jemaat maupun sinode. Membuat kegiatan pendidikan dan pelatihan tentang rekonsiliasi dan perdamaian untuk para pelayan khusus (Pendeta, Penatua, Diaken, Pengurus Biro, Badan Lembaga, dan lain-lain) dan untuk warga Gereja agar mereka dapat menjadi pelaku rekonsiliasi dan perdamaian di tengah jemaat dan masyarakat.

Ketiga, dalam kaitan dengan realita pusara korban yang dilengkapi dengan pernyataan-pernyataan seperti "jangan sia-siakan perjuanganku” dan "darah martir adalah benih bagi Gereja," menurut penulis, perlu ada kesepakatan bersama dalam masyarakat dan jemaat untuk memikirkan ulang penggunaan ungkapan-ungkapan tersebut. Hal ini dapat dilakukan dengan cara menghapus, menggantikan, dan menambahkan pernyataan yang lebih mengandung nilai-nilai tanpa kekerasan; misalnya "damailah saudaraku" atau "bencilah kekerasan," dan lainlain. Sedangkan pernyataan-pernyataan yang lain seperti "martir jemaat," kutipan dari Filipi 1:21, Mazmur 116:15, serta kata dodar, yang ada dalam pemahaman masyarakat Halmahera perlu ditransformasikan sebagaimana yang telah penulis upayakan dalam tulisan ini, dan disosialisasikan kepada seluruh masyarakat dan warga jemaat.

\section{DAFTAR RUJUKAN}

Adeney-Risakotta, Bernard. “Teori Kekuasaan Dari Bawah." Renai 3/1 (Juli, 2002): 123-141. 
Adriolo, Karin. “Membunuh Melalui Bunuh Diri - Tiga Episode dari Sejarah Islam." Dalam Ahmad Norma Permata, ed., Agama dan Terorisme. Surakarta: Muhamadiyah University Press, 2006, hlm. 35-55.

Appleby, R.S., The Ambivalence of The Sacred: Religion, Violence, and Reconciliation. New York: Rowman \& Littlefield Publishers, 2000.

Barclay, William. Pemahaman Alkitab Setiap Hari: Surat Filipi, Kolose, 1 dan 2 Tesalonika. Terj. Ferdy Suleeman. Jakarta: BPK Gunung Mulia. 2006.

Carney, Glandion \& William Long. Longing For God: Prayer \& the Rhythms of Life. Downers Grove, IL: Intervarsity Press, 1993.

Freud, Sigmund. A General Introduction To Psychoanalysis (Pengantar Umum Psikoanalisis). Pernerjemah dan penyunting Haris Setiowati. Yogyakarta: Pustaka Pelajar, 2006.

Gerrit Singgih, Emanuel. Mengatisipasi Masa Depan: Berteologi Dalam Konteks di Awal Milenium III. Jakarta: BPK Gunung Mulia, 2004.

Girard, René. Ayub Korban Masyarakat. Terj. Daniel K. Listijabudi. Jakarta: BPK Gunung Mulia, 2003.

Haag, Herbert. Ensiklopedi Alkitab Masa Kini. Jilid I. Jakarta: Yayasan Komunikasi Bima Kasih/OFM, 1992. Kamus Alkitab. Ende: Nusa Indah, 1992.

Haire, J. Sifat dan Pergumulan Gereja Halmahera 1941-1979. Jakarta: BPK Gunung Mulia, 1998.

Houtart, Francois. "Kultus, Kekerasan Atas Nama Agama; Sebuah Panorama." Dalam Wim Beuken, et al., eds., Agama Sebagai Sumber Kekerasan? Terj. Imam Baehaqie. Yogyakarta: Pustaka Pelajar, 2003, hlm. ix-x.

Iannaccone, Laurence R. and Eli Berman. "Religious Extremism: The good, The Bad, and The Deadly." Public Choice 4 (July, 2006): 109129.

Kutjame, S. "Pengaruh Agama Asli dalam Kehidupan Gereja Masehi Injili di Halmahera." Dalam H. G. Schuurman, ed., Seri Sejarah GMIH no. 5. Tobelo: STT GMIH, 1995), hlm. 6-43.

Martodirjo, Haryo S. "Organisasi Sosial Orang Tugutil di Halmahera." Dalam L.E. Visser, Halmahera and Beyond. Leiden: KITLV Press, 1994, hlm. 120. 
Poerwadarminta, W.J.S. Kamus Umum Bahasa Indonesia. Edisi ketiga. Jakarta: Balai Pustaka, 2006.

Schirh, Lisa. "Ritual Reconsiliation: Transforming Identity/Reframing Conflict." In Mohammed Abu-Nimer, ed. Reconciliation Justice and Coexistence: Theory and Practice. Lanham: Lexington Books, 2001, p. 147.

Schreiter, Robert J. Reconciliation, Mission and Ministry in a Changing Social Order. New York: Maryknol, Orbis Books, 1998.

- Rekonsiliasi Membangun Tatanan Masyarakat Baru. Terjemahan Biro Penerbit Propinsi SVD. Ende: Nusa Indah, 2000.

Sindhunata. Kambing Hitam: Teori René Girard. Jakarta: Gramedia, 2006.

Sobrino, Jon. “Agama dan Kekerasan: Masalah dan Pemecahannya kasus Amerika Latin: Guatemala/El- Savador." Dalam Wim Beuken dan Karl-Josef Kuschel, et al. Agama Sebagai Sumber Kekerasan? Terj. Imam Baehaqie. Yogyakarta: Pustaka Pelajar, 2003, hlm. 82-87.

Sutanto, Hasan. Perjanjian Baru Interlinear Yunani-Indonesia dan Korkondansi Perjanjian Baru. Jilid II. Jakarta: Lembaga Alkitab Indonesia, 2006.

Welem, F. D. Riwayat Hidup Singkat Tokoh-tokoh Dalam Sejarah Gereja. Jakarta: BPK Gunung Mulia, 2003. 